\title{
On the Correlation between Electronic Intramolecular Delocalization and Au-S Bonding Strength of Ruthenium Tetraammine SAMs
}

\author{
Solange de O. Pinheiro, ${ }^{a}$ Tércio de F. Paulo, ${ }^{a}$ Maria A. S. da Silva, ${ }^{a}$ Gustavo F. S. Andrade, ${ }^{b}$ \\ Márcia L. A. Temperini, ${ }^{b}$ Idalina M. M. de Carvalho, ${ }^{a}$ Jackson R. de Sousa, ${ }^{a}$ Luiz G. de F. Lopes, ${ }^{a}$ \\ Francisco A. Dias-Filho, ${ }^{a}$ Eduardo H. S. Sousa, ${ }^{a}$ Elisane Longhinotti, ${ }^{c}$ Marcelo O. Santiago, ${ }^{d}$ \\ Ícaro de S. Moreira ${ }^{\dagger, a}$ and Izaura C. N. Diógenes $*, a$
}

${ }^{a}$ Departamento de Química Orgânica e Inorgânica, Universidade Federal do Ceará, CP 6021, 60455-970 Fortaleza-CE, Brazil

${ }^{b}$ Instituto de Química, Universidade de São Paulo, Cidade Universitária, CP 26077, 05599-970 São Paulo-SP, Brazil

${ }^{c}$ Departamento de Química Analítica e Físico-Química, Universidade Federal do Ceará, CP 6035, 60455-970 Fortaleza-CE, Brazil

${ }^{d}$ Campus Cariri, Universidade Federal do Ceará, Av. Tenente Raimundo Rocha s/n, 63040-360 Juazeiro do Norte-CE, Brazil

Complexos do tipo trans- $\left[\mathrm{Ru}(\mathrm{L})\left(\mathrm{NH}_{3}\right)_{4}\left(\mathrm{~L}^{\prime}\right)\right]\left(\mathrm{PF}_{6}\right)_{\mathrm{n}}$, onde $\mathrm{L}=4$-cianopiridina (CNpy), $\mathrm{NCS}^{-}$, $\mathrm{CN}^{-}$, e L' = CNpy, 1,4-ditiano (1,4-dt), 4-mercaptopiridina (pyS) e tionicotinamida (tna), foram sintetizados e caracterizados. SAMs sobre ouro formadas com os complexos que contêm ligantes sulfurados foram estudadas por desorção redutiva e espectroscopia SERS. Dependendo da natureza do ligante L', a capacidade retiradora do ligante CNpy mostrou ser forte o suficiente para oxidar parcialmente o átomo de rutênio e, em consequência, deslocalizar densidade eletrônica $\sigma$ do ligante localizado em posição trans. Os resultados de desorção redutiva mostraram que a estabilidade das SAMs formadas está diretamente relacionada a este efeito.

Trans- $\left[\mathrm{Ru}(\mathrm{L})\left(\mathrm{NH}_{3}\right)_{4}\left(\mathrm{~L}^{\prime}\right)\right]\left(\mathrm{PF}_{6}\right)_{\mathrm{n}}$ type complexes, where $\mathrm{L}=4$-cyanopyridine $(\mathrm{CNpy}), \mathrm{NCS}^{-}$, $\mathrm{CN}^{-}$, and $\mathrm{L}^{\prime}=\mathrm{CNpy}, 1$,4-dithiane (1,4-dt), 4-mercaptopyridine (pyS) and thionicotinamide (tna), were synthesized and characterized. SAMs on gold of the complexes containing sulfur were studied by reductive desorption and SERS spectroscopy. Depending on the nature of L', the withdrawing capability of the CNpy ligand is strong enough to partially oxidize the ruthenium atom and, as a consequence, delocalize the $\sigma$ electronic density from the trans located ligand. The reductive desorption results showed that the stability of the SAMs is directly related to this effect.

Keywords: ligand effects, sulfur-containing ligands, 4-cyanopyridine, self-assembled monolayers, SERS

\section{Introduction}

The quest for molecules that contain both a head group and a functional terminal group positioned at a known distance from each other and that spontaneously adsorb on metallic surfaces has grown during the past decades, especially due to a high degree of surface functionality. ${ }^{1-3}$

*e-mail: izaura@dqoi.ufc.br

$\dagger$ In memoriam
Self-assembled monolayers (SAMs) formed on gold with thiol head group containing molecules, for instance, have been exploited as electrodes in several areas such as the active control of interfacial properties, ${ }^{4,5}$ electrochemical sensors, ${ }^{6}$ biosensors ${ }^{7,8}$ and molecular electronics. ${ }^{4,9,10}$ One of the biggest challenges in the study of electrochemical interfaces, however, has been the awareness of the electronic, structural aspects, and specific chemistry of the head group, also known as "alligator clip", and its effect on the characteristics and stability of SAMs. Thiolate is 
believed to form a structural contact through a Lewis acidbase interaction with the gold surface, which can be only $\sigma$ or $\sigma$ and $\pi$ depending on the surface active site. ${ }^{2,11}$ The fundamental nature of chemical bonds, therefore, has been the subject of great interest so far. Specifically concerning transition metal atoms, the field of inorganic chemistry gained a new focus upon Taube's approach to the $\pi$-backbonding interaction. ${ }^{12}$ SERS (Surface Enhanced Raman Scattering) spectroscopy has been used to study this kind of interaction in SAMs formed on gold with $\left[\mathrm{M}(\mathrm{CN})_{5} \mathrm{~L}\right]^{3-}$ and $\left[\mathrm{M}\left(\mathrm{NH}_{3}\right)_{4} \mathrm{LL}^{\prime}\right]^{2+}$ type complexes, where $\mathrm{L}=N$-heterocyclic and sulfur containing molecules, and $\mathrm{M}=\mathrm{Fe}, \mathrm{Ru} .{ }^{7,13-15}$

Aiming to contribute to the understanding of the interaction between the gold surface and sulfur containing molecules, SERS spectroscopy and electrochemical reductive desorption were used to study SAMs formed with tetraammine ruthenate complexes on gold polycrystalline surface. Electronic studies in homogeneous medium were performed in order not only to characterize the isolated complexes, but also to explain the electrochemical reductive desorption data obtained for the sulfur containing SAMs.

\section{Results and Discussion}

\section{Characterization of the complexes}

The infrared (IR) and Raman vibrational spectra of the isolated complexes were evaluated based on the spectra of similar complexes and of the uncoordinated Lewis bases. For the 4-mercaptopyridine (pyS) containing compounds, $\left[\mathrm{Ru}(\mathrm{CNpy})\left(\mathrm{NH}_{3}\right)_{4}(\mathrm{pyS})\right]\left(\mathrm{PF}_{6}\right)_{2}$ and $\left[\mathrm{Ru}(\mathrm{CN})\left(\mathrm{NH}_{3}\right)_{4}(\mathrm{pyS})\right]$ $\left(\mathrm{PF}_{6}\right)$, the band observed at $1102 \mathrm{~cm}^{-1}$, known as $\mathrm{X}$-sensitive band due to a coupling of the $v(C S)$ stretching mode with the $12 \mathrm{a}_{1}$ ring breathing mode of the pyS species, ${ }^{16-19}$ does not present frequency shift upon coordination to the ruthenium center. This observation indicates that the coordination does not occur via the sulfur atom.

The bands assigned to the $v(\mathrm{CS})$ modes $^{19-21}$ are observed from 250 to $750 \mathrm{~cm}^{-1}$ for $\left[\mathrm{Ru}(\mathrm{CNpy})\left(\mathrm{NH}_{3}\right)_{4}(1,4-\mathrm{dt})\right]\left(\mathrm{PF}_{6}\right)_{2}$, where 1,4-dt $=1,4$-dithiane. From 800 to $2500 \mathrm{~cm}^{-1}$, the vibrational spectra of this complex are dominated by the CNpy vibrational modes. ${ }^{22-25}$ The detailed assignment of the vibrational modes for the $\left[\mathrm{Ru}(\mathrm{CNpy})\left(\mathrm{NH}_{3}\right)_{4}(\mathrm{pyS})\right]\left(\mathrm{PF}_{6}\right)_{2}$ and $\left[\mathrm{Ru}(\mathrm{CNpy})\left(\mathrm{NH}_{3}\right)_{4}(1,4-\mathrm{dt})\right]\left(\mathrm{PF}_{6}\right)_{2}$ complexes can be found in a previous report. ${ }^{14}$

The bands observed at 2087 and $2055 \mathrm{~cm}^{-1}$ in the vibrational spectra of $\left[\mathrm{Ru}(\mathrm{CN})\left(\mathrm{NH}_{3}\right)_{4}(\mathrm{pyS})\right]\left(\mathrm{PF}_{6}\right)$ and $\left[\mathrm{Ru}(\mathrm{CNpy})\left(\mathrm{NH}_{3}\right)_{4}(\mathrm{CN})\right]\left(\mathrm{PF}_{6}\right)$, respectively, are assigned ${ }^{26}$ to the $v(\mathrm{C} \equiv \mathrm{N})$ stretching mode of the $\mathrm{CN}^{-}$ligand. The observation of the $v(\mathrm{C} \equiv \mathrm{N})$ mode at different frequencies reflects the competition between the ligands that are located on the $\mathrm{z}$ axis for the $\pi$ electronic density. Based on the frequency values, one can conclude that the CNpy ligand has a lower $\pi$ withdrawing capability than the pyS ligand, i.e., the CNpy ligand allows a stronger $\pi$-back-bonding interaction toward the $\mathrm{CN}^{-}$species.

For the $\left[\mathrm{Ru}(\mathrm{CNpy})\left(\mathrm{NH}_{3}\right)_{4}(\mathrm{tna})\right]\left(\mathrm{PF}_{6}\right)_{2}$ complex, relevant bands concerning the tha (thionicotinamide) ligand are observed at 862,1030, 1290 and $1597 \mathrm{~cm}^{-1}$, which are assigned, ${ }^{18,23-25,27}$ respectively, to the $v(\mathrm{CS}), v(\mathrm{CN})$, $v(\mathrm{C}=\mathrm{S})$, and $\delta\left(\mathrm{NH}_{2}\right)$ coupled with $v(\mathrm{C}=\mathrm{N})$ and $\delta(\mathrm{CH})$ vibrational modes. These are typical bands assigned to the $\mathrm{R}-\mathrm{C}\left(\mathrm{NH}_{2}\right)=\mathrm{S}$ group of tna. ${ }^{27}$ Table 1 presents the most relevant bands for the thiocyanate containing complexes.

In accordance with the resonance structures proposed by Jones $^{30}$ for the thiocyanate ion, $N$-bonding favors a structure that results in a decrease in $\mathrm{CN}$ bond order and vibrational frequency. An opposite behavior should be expected for the CS bonding and vibrational frequency. Normally, however, the $\mathrm{CN}$ stretching mode, $\mathrm{v}(\mathrm{CN})$, can exhibit more than one component due to distortions from regular octahedral symmetry which destroy the degeneracy of the band. ${ }^{31}$ In addition, there are $N$-bonded examples in which this mode is observed over $2090 \mathrm{~cm}^{-1}$, thus making a risk to consider this band alone as a criterion of bonding. ${ }^{28}$ An effect of electronic density delocalization upon coordination must be involved in the $v(\mathrm{CN})$ frequencies. In fact, this mode is observed as only one component at $2095 \mathrm{~cm}^{-1}$

Table 1. Frequencies $\left(\mathrm{cm}^{-1}\right)$ of the $v(\mathrm{CN})$ and $v(\mathrm{CS})$ vibrational modes of the $\mathrm{NCS}^{-}$ligand

\begin{tabular}{|c|c|c|c|c|}
\hline \multirow[t]{2}{*}{ Complex ${ }^{c}$} & \multicolumn{2}{|c|}{$v(\mathrm{CN})$} & \multicolumn{2}{|c|}{$v(\mathrm{CS})$} \\
\hline & Raman & IR & Raman & IR \\
\hline$\left[\mathrm{Ru}(\mathrm{CNpy})\left(\mathrm{NH}_{3}\right)_{4}(\underline{\mathrm{NCS}})\right]\left(\mathrm{PF}_{6}\right)$ & $\begin{array}{l}2037(w) \\
2131(w)\end{array}$ & $\begin{array}{l}2055(\mathrm{~s}) \\
2116(\mathrm{~s})\end{array}$ & $854(\mathrm{~m})$ & $778(\mathrm{~s})$ \\
\hline$\left[\mathrm{Ru}(\underline{\mathrm{NCS}})\left(\mathrm{NH}_{3}\right)_{4}(\underline{\mathrm{NCS}})\right]$ & $\begin{array}{l}2100(\mathrm{~m}) \\
2107(\mathrm{w})\end{array}$ & $\begin{array}{l}2063(\mathrm{~m}) \\
2002(\mathrm{sh})\end{array}$ & $827(\mathrm{~s})$ & $797(\mathrm{~m})$ \\
\hline${ }^{\mathrm{a}}\left(\mathrm{Bu}_{4} \mathrm{~N}\right)_{3}\left[\mathrm{Ru}(\underline{\mathrm{NCS}})_{6}\right]$ & & 2095(s) & & $812(\mathrm{~m})$ \\
\hline${ }^{\mathrm{b}} \mathrm{NCS}^{-}$ & & 2053 & & 746 \\
\hline
\end{tabular}

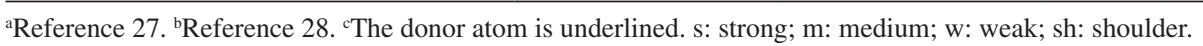


for $\left(\mathrm{Bu}_{4} \mathrm{~N}\right)_{3}\left[\mathrm{Ru}(\underline{\mathrm{NCS}})_{6}\right]$ (Table 1), despite the expected decrease in the vibrational frequency in comparison to free thiocyanate. For the $\left[\mathrm{Ru}(\mathrm{CNpy})\left(\mathrm{NH}_{3}\right)_{4}(\underline{\mathrm{NCS}})\right]\left(\mathrm{PF}_{6}\right)$ and $\left[\mathrm{Ru}(\underline{\mathrm{NCS}})\left(\mathrm{NH}_{3}\right)_{4}(\underline{\mathrm{NCS}})\right]$ complexes, a comparative analysis shows that the replacement of one $\mathrm{NCS}^{-}$species by the CNpy ligand has a considerable effect on the $v(\mathrm{CN})$ frequency. The analysis of the CS stretching mode, $v(\mathrm{CS})$, on the other hand, does not seem to be so complex. Upon coordination, this mode presents a shift toward higher frequencies being consistent with an $\mathrm{N}$-bonding assignment. $^{32}$

For all the cyanopyridine (CNpy) containing complexes, the $v(\mathrm{C} \equiv \mathrm{N})$ mode of the CNpy moiety presents a shift from $2239 \mathrm{~cm}^{-1}$ (for free CNpy) to $\mathrm{ca} .2000 \mathrm{~cm}^{-1}$ upon coordination (Table 2), indicating that the bonding occurs through the nitrile group. ${ }^{33}$ The values of the $v(\mathrm{C} \equiv \mathrm{N})$ shift, $\Delta v(\mathrm{C} \equiv \mathrm{N})$, presented in Table 2 illustrate the $\pi$-back-bonding interaction capability of the $\left[\mathrm{Ru}\left(\mathrm{NH}_{3}\right)_{4} \mathrm{~L}^{\prime}\right]^{\mathrm{n+}}$ moiety towards the CNpy ligand. In comparison to $\mathrm{L}^{\prime}=\mathrm{NH}_{3}\left(\Delta v(\mathrm{C} \equiv \mathrm{N})=-64 \mathrm{~cm}^{-1}\right),{ }^{34}$ the observed lower values when $\mathrm{L}^{\prime}=$ pyS , tna, $\mathrm{CN}^{-}$and $\mathrm{CNpy}$ indicate the competition between these ligands for the $\pi$ electronic density of the ruthenium. For the 1,4-dt ligand, the higher $\Delta v(\mathrm{C} \equiv \mathrm{N})\left(-41 \mathrm{~cm}^{-1}\right)$ is related to a relatively low $\mathrm{E}_{1 / 2}$ value in comparison to the $N$-heterocyclic ligands. This is an intriguing observation since the $\mathrm{E}_{1 / 2}$ values of the $\mathrm{Ru}^{\mathrm{III/II}}$ process for $\left[\mathrm{Ru}(\mathrm{CN})_{5} \mathrm{~L}\right]^{3-}$ and $\left[\mathrm{Ru}\left(\mathrm{NH}_{3}\right)_{5} \mathrm{~L}\right]^{2+}$ type complexes are usually at least $150 \mathrm{mV}$ more positive when $\mathrm{L}$ is a dithioether ligand. ${ }^{35}$ For $\left[\mathrm{Ru}(\mathrm{CNpy})\left(\mathrm{NH}_{3}\right)_{4}(1,4-\mathrm{dt})\right]^{2+}$, however, the presented result suggests that there is almost no competition between the two axial ligands, CNpy and 1,4-dt. Electronic properties of the isolated $\left[\mathrm{Ru}(\mathrm{CNpy})\left(\mathrm{NH}_{3}\right)_{4} \mathrm{~L}^{ }\right]^{\mathrm{n}+}$ type complexes are shown in Table 2 along with some data available for similar compounds.

Besides the metal-to-ligand charge transfer (MLCT) transition $\mathrm{p}_{\pi} *(\mathrm{CNpy}) \leftarrow \mathrm{d}_{\pi}\left(\mathrm{Ru}^{\mathrm{II}}\right)$, whose assignment was based on the electronic spectra of $\left[\mathrm{Ru}(\mathrm{CNpy})\left(\mathrm{NH}_{3}\right)_{4}\left(\mathrm{H}_{2} \mathrm{O}\right)\right]^{2+}$ and $\left[\mathrm{Ru}(\mathrm{CNpy})\left(\mathrm{NH}_{3}\right)_{4}(\mathrm{CNpy})\right]^{2+}$ (see Figure $\mathrm{S} 1$ in Supplementary Information), all the isolated complexes present an additional MLCT absorption at a higher energy.
This absorption is assigned to a MLCT transition involving the second ligand as acceptor. ${ }^{36}$ In the first column of Table 2, going from 1,4-dt to $\mathrm{CN}^{-}$, an increase in the energy of the MLCT transition $\left(\mathrm{p}_{\pi}{ }^{*}(\mathrm{CNpy}) \leftarrow \mathrm{d}_{\pi}\left(\mathrm{Ru}^{\mathrm{II}}\right)\right.$ is observed, suggesting an increase in the $\pi$ acid strength of the $L$ ' ligand. These results also indicate that, when the $\pi$ withdrawing capability of the L' ligand is significantly different from that of the CNpy moiety $\left(\mathrm{L}^{\prime}=1,4-\mathrm{dt}, \mathrm{NCS}^{-}\right.$and $\left.\mathrm{CN}^{-}\right)$, the oxidation of the metal is facilitated, as can be seen from the $\mathrm{E}_{1 / 2}$ values (Table 2). On the other hand, when the L' ligands present similar $\pi$ withdrawing capabilities ( $\mathrm{L}^{\prime}=$ tna and pyS) compared to CNpy, the electronic density appears to be strongly delocalized toward the axial ligands thus stabilizing the reduced state of the metal center. Therefore, in a qualitative sense, one can conclude that the LUMO orbitals of the 1,4-dt, $\mathrm{NCS}^{-}$and $\mathrm{CN}^{-}$ligands have considerably different energies when compared to those of the CNpy ligand. Particularly for $\mathrm{L}^{\prime}=\mathrm{CN}^{-}$, this conclusion is reinforced by the lowest shift of the $v(\mathrm{C} \equiv \mathrm{N})$ mode of the CNpy ligand $\left(\Delta v(\mathrm{C} \equiv \mathrm{N})=-32 \mathrm{~cm}^{-1}\right)$. The correlation between the $v(\mathrm{C} \equiv \mathrm{N})$ shift and the $\pi$ acid strength is based on the fact that the $\pi$-back-bonding interaction populates antibonding orbitals of the nitrile fragment of the CNpy moiety. Accordingly, when the $\pi$ withdrawing capability of the L' ligand is greater than that of CNpy, the bond order of the $\mathrm{C} \equiv \mathrm{N}$ group in $\mathrm{CNpy}$ increases, thus increasing the frequency of this vibrational mode.

The fact that the electronic spectral data generally indicate less back-bonding than do the potential data is assigned to the $\sigma$ interaction in $\mathrm{Ru}^{\mathrm{II}}$ complexes, which is detectable by electrochemical but not spectral measurements. ${ }^{37}$ By keeping this consideration in mind, it is reasonable to conclude that there is an enhancement of the $\sigma$ contribution when $\mathrm{L}^{\prime}=1,4-\mathrm{dt}, \mathrm{NCS}^{-}$and $\mathrm{CN}^{-}$, although the $\pi$-acceptor character of these ligands should not be ruled out. ${ }^{38-40}$

The $\pi$ stabilization potential, $\mathrm{E}_{\pi}$, can be estimated by means of electrochemistry if the average potential for the $\mathrm{Ru}^{\mathrm{IIIII}}$ redox couple given by the aquopentaammine $(0.07 \mathrm{~V})$

Table 2. Absorption properties of the $\mathrm{p}_{\pi}{ }^{*}(\mathrm{CNpy}) \leftarrow \mathrm{d}_{\pi}\left(\mathrm{Ru}^{\mathrm{II}}\right)$ MLCT transition; $\mathrm{E}_{1 / 2}$ values for $\mathrm{Ru}^{\mathrm{IIIII}}$ redox process $(\mathrm{V} v s$. NHE); $\pi$-back-bonding potential $\left(\mathrm{E}_{\pi}, \mathrm{V} v\right.$ s. NHE) and frequency values $\left(\mathrm{cm}^{-1}\right)$ for the $v(\mathrm{C} \equiv \mathrm{N})$ mode of $\mathrm{CNpy}$ in $\left[\mathrm{Ru}(\mathrm{CNpy})\left(\mathrm{NH}_{3}\right)_{4} \mathrm{~L}^{\prime}\right]^{\mathrm{n}+}$ type complexes

\begin{tabular}{|c|c|c|c|c|c|}
\hline $\mathrm{L}^{\prime}$ & $\lambda_{(\max )} / \mathrm{nm}\left(\varepsilon / \mathrm{L} \mathrm{mol}^{-1} \mathrm{~cm}^{-1}\right)$ & ${ }^{\mathrm{a}} \mathrm{E}_{1 / 2}$ & $\mathrm{E}_{\pi}$ & $\Delta v(\mathrm{C} \equiv \mathrm{N})$ & Reference \\
\hline $1,4-\mathrm{dt}$ & $557\left(1.60 \times 10^{4}\right)$ & 0.67 & 0.61 & -41 & 14 \\
\hline tna & $550\left(1.87 \times 10^{4}\right)$ & 1.03 & 0.97 & -35 & This work \\
\hline${ }^{b} \underline{\mathrm{NCS}^{-}}$ & $548\left(2.50 \times 10^{3}\right)$ & 0.65 & 0.59 & -36 & This work \\
\hline pyS & $542\left(1.23 \times 10^{4}\right)$ & 1.00 & 0.94 & -35 & 14 \\
\hline CNpy & $512\left(1.96 \times 10^{3}\right)$ & 1.10 & 1.04 & -36 & This work \\
\hline$\underline{\mathrm{CN}}^{-}$ & $446\left(1.05 \times 10^{3}\right)$ & 0.79 & 0.73 & -32 & This work \\
\hline
\end{tabular}

${ }^{a}$ Cyclic voltammetry in acetonitrile containing $0.1 \mathrm{~mol} \mathrm{~L}^{-1}$ tbap. ${ }^{\mathrm{b}} N$-bonded. ${ }^{\mathrm{c}}$ The donor atom is underlined. 
and the hexaammine $(0.05 \mathrm{~V})^{41}$ is used as a measure of the level of zeroth-order (no $\pi$-back-bonding interaction), $\mathrm{E}_{\pi}=\mathrm{E}_{1 / 2}-0.06 \mathrm{~V}$. The calculated $\mathrm{E}_{\pi}$ values displayed in Table 2 are consistent with previously reported data ${ }^{37}$ in which the $\pi$-back-bonding interaction is greater for orbitals that are close in energy. For the used ligands and considering the molecular orbital parameters reported for $\mathrm{Ru}^{\mathrm{II}}$ complexes, ${ }^{41}$ there is a greater energy similarity between the $\mathrm{t}_{2 \mathrm{~g}}$ orbitals of the ruthenium and the $\pi^{*}$ orbitals of the $N$-heterocyclic ligands tna, pyS and CNpy. Among these, the most positive $E_{1 / 2}$ value observed when $L^{\prime}=C N p y$ is consistent with the assertion that nitrile complexes as a group display more positive formal potential values than the pyridines. ${ }^{42}$

\section{Characterization of SAMs}

The immersion of gold polycrystalline surfaces for $30 \mathrm{~min}$ in a $2.0 \mathrm{mmol} \mathrm{L} \mathrm{L}^{-1}$ aqueous solutions of $\left[\mathrm{Ru}(\mathrm{CNpy})\left(\mathrm{NH}_{3}\right)_{4}(\mathrm{pyS})\right]^{2+},\left[\mathrm{Ru}(\mathrm{CNPy})\left(\mathrm{NH}_{3}\right)_{4}(1,4-\mathrm{dt})\right]^{2+}$, $\left[\mathrm{Ru}(\mathrm{CNpy})\left(\mathrm{NH}_{3}\right)_{4}(\mathrm{tna})\right]^{2+}$ and $\left[\mathrm{Ru}(\mathrm{CNpy})\left(\mathrm{NH}_{3}\right)_{4}(\underline{\mathrm{NCS}})\right]^{+}$ results in SAMs which were characterized by reductive desorption and SERS (surface-enhanced Raman scattering) spectroscopy.

\section{Reductive desorption measurements}

Based on the well established method of reductive desorption of thiolates from gold surface in alkaline medium, ${ }^{43-47}$ which takes into account the RSAu $+\mathrm{e}^{-} \rightarrow$ $\mathrm{RS}^{-}+$Au reaction, the surface coverage, $\Gamma$, of the adsorbed complexes was calculated according to equation 1 :

$\Gamma=\sigma_{\mathrm{rd}} / \mathrm{nF}$

where $\sigma_{\mathrm{rd}}$ is the reductive charge density, $\mathrm{n}$ is the number of electrons involved in the electrode reaction, $\mathrm{F}$ is the Faraday constant. The application of a linear sweep voltage in $0.5 \mathrm{~mol} \mathrm{~L}^{-1} \mathrm{KOH}$ solution produces a single wave whose reductive desorption potential, $\mathrm{E}_{\mathrm{rd}}$, reflects the strength of the Au-S bonding. In addition, the $\mathrm{E}_{\mathrm{rd}}$ values have been used to indicate which kind of interaction, if only $\sigma$ or $\sigma$ and $\pi$, is involved in the Au-S bonding. ${ }^{16,43,48-52}$ Values of $\mathrm{E}_{\mathrm{rd}}, \sigma_{\mathrm{rd}}$ and $\Gamma$ are displayed in Table 3 .

Typical values of $\sigma_{\mathrm{rd}}$ for the desorption of alkanethiolates

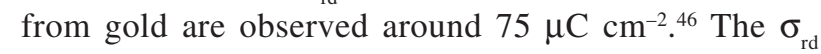
values observed for the complexes range from 2.5 to $9.3 \mu \mathrm{C} \mathrm{cm}^{-2}$. These lower values are assigned to the higher volume of the complexes as well as to the repulsion between the adjacent charged molecules. Concerning the $\mathrm{E}_{\mathrm{rd}}$ parameter, for the SAMs formed with $\left[\mathrm{M}(\mathrm{CN})_{5}(\mathrm{pyS})\right]^{3-}$ type complexes where $\mathrm{M}=\mathrm{Fe}, \mathrm{Ru},{ }^{50} \mathrm{a}$ shift toward negative values is observed in comparison to the SAM formed with the free pyS,,$^{50-52}$ as a consequence of the $\pi$-back-bonding effect that increases the electronic density on the pyS moiety improving the chemisorption process. For the isolated CNpy tetraammine ruthenate complexes, however, a meaningful shift of the $\mathrm{E}_{\mathrm{rd}}$ value is not observed for the tna and pyS containing complexes in relation to the SAMs formed with the non-coordinated species. This result reflects the competition with the CNpy ligand, which reduces the electronic delocalization toward the adsorption sites, thus decreasing the strength of the $\mathrm{Au}-\mathrm{S}$ bonding. Another factor that might be considered is the electrostatic effect associated to the electronic density introduced by the complex on the surface, which would cause a positive shift in the reductive peak potential. However, as observed for the SAM formed with the $\left[\mathrm{Ru}(\mathrm{CN})_{5}(\mathrm{pyS})\right]^{3-}$ complex on gold, ${ }^{7,51,52}$ the back-bonding interaction toward the adsorption moiety improving the $\mathrm{Au}-\mathrm{S}$ chemisorption process seems to prevail over the electrostatic effect. In fact, the withdrawing capability

Table 3. Values of $\mathrm{E}_{\mathrm{rd}}, \sigma_{\mathrm{rd}}, \Gamma^{\mathrm{a}}$, and suggested types of interaction for SAMs formed with sulfur-containing complexes on gold. Data on pyS, 1,4-dt and tna are also presented for comparison

\begin{tabular}{|c|c|c|c|c|c|}
\hline Species & $\mathrm{E}_{\mathrm{rd}}, \mathrm{V}$ vs. $\mathrm{Ag}|\mathrm{AgCl}| \mathrm{Cl}^{-}$ & $\begin{array}{c}\Gamma \times 10^{11} / \\
\left(\mathrm{mol} \mathrm{cm}{ }^{-2}\right)\end{array}$ & $\begin{array}{c}\sigma_{\mathrm{rd}} / \\
\left(\mu \mathrm{C} \mathrm{\textrm {cm } ^ { - 2 }}\right)\end{array}$ & $\begin{array}{c}\mathrm{Au}-\mathrm{S} \\
\text { Interaction }\end{array}$ & Reference \\
\hline pyS & $-0.55^{*}$ & 64.0 & 61.4 & $\sigma$ & $15,47,49,50$ \\
\hline $1,4-\mathrm{dt}$ & $-0.87( \pm 0.026)$ & 21.6 & 20.8 & $\sigma$ and $\pi$ & 48 , this work \\
\hline tna & -0.88 & 82.3 & 84.6 & $\sigma$ and $\pi$ & 52 \\
\hline$\left[\mathrm{Ru}(\mathrm{CNpy})\left(\mathrm{NH}_{3}\right)_{4}(\mathrm{pyS})\right]^{2+}$ & -0.52 & 4.5 & 4.30 & $\sigma$ & 14 \\
\hline$\left[\mathrm{Ru}(\mathrm{CNPy})\left(\mathrm{NH}_{3}\right)_{4}(1,4-\mathrm{dt})\right]^{2+}$ & -0.64 & 9.6 & 9.28 & $\sigma$ and $\pi$ & 14 \\
\hline$\left[\mathrm{Ru}(\mathrm{CNpy})\left(\mathrm{NH}_{3}\right)_{4}(\mathrm{tna})\right]^{2+}$ & $-0.94( \pm 0.030)$ & 2.8 & 2.7 & $\sigma$ and $\pi$ & This work \\
\hline$\left[\mathrm{Ru}(\mathrm{CNpy})\left(\mathrm{NH}_{3}\right)_{4}(\underline{\mathrm{NCS}})\right]^{+}$ & $-0.68( \pm 0.025)$ & 2.6 & 2.5 & $\sigma$ & This work \\
\hline
\end{tabular}

*This value is an average, calculated from reported data. ${ }^{2}$ Reductive desorption parameters $\left(\mathrm{E}_{\mathrm{rd}}, \sigma_{\mathrm{rd}}, \Gamma\right)$ were determined from LSV curves acquired in $0.5 \mathrm{~mol} \mathrm{~L}^{-1} \mathrm{KOH}$ solution at $50 \mathrm{mV} \mathrm{s}^{-1}$. Gold substrates were modified after 30 min of immersion in $2.0 \mathrm{mmol} \mathrm{L}^{-1}$ aqueous solution of the complexes. 
of the CNpy moiety is strongly evidenced in the SAM formed with $\left[\mathrm{Ru}(\mathrm{CNPy})\left(\mathrm{NH}_{3}\right)_{4}(1,4-\mathrm{dt})\right]^{2+}$. For this SAM, a positive shift is observed in relation to the SAM formed with free $1,4-\mathrm{dt}$ (from $-0.87 \mathrm{~V}$ to $-0.64 \mathrm{~V}$ ). As previously discussed, the electronic delocalization toward the CNpy ligand affects the $\sigma$ electronic density on the 1,4-dt ligand, thus reducing the strength of the $\mathrm{Au}-\mathrm{S}$ bonding and, therefore, making the desorption of the $[\mathrm{Ru}(\mathrm{CNPy})$ $\left.\left(\mathrm{NH}_{3}\right)_{4}(1,4-\mathrm{dt})\right]^{2+}$ complex from the gold surface easier in relation to the SAM formed with free 1,4-dt.

\section{SERS results}

SERS spectra were obtained for the SAMs formed with the sulfur containing complexes, $[\mathrm{Ru}(\mathrm{CNpy})$ $\left.\left(\mathrm{NH}_{3}\right)_{4}(\mathrm{pyS})\right]^{2+},\left[\mathrm{Ru}(\mathrm{CNpy})\left(\mathrm{NH}_{3}\right)_{4}(1,4-\mathrm{dt})\right]^{2+},[\mathrm{Ru}(\mathrm{CNpy})$ $\left(\mathrm{NH}_{3}\right)_{4}$ (tna) $]^{2+}$ and $\left[\mathrm{Ru}(\mathrm{CNpy})\left(\mathrm{NH}_{3}\right)_{4}(\mathrm{NCS})\right]^{+}$, after $30 \mathrm{~min}$ of immersion in a $2.0 \mathrm{mmol} \mathrm{L}^{-1}$ aqueous solution of the respective compounds.

Previous publications ${ }^{7,13,16,17}$ have shown that the chemisorption of pyS containing complexes on gold occurs through the sulfur atom with a vertical orientation in relation to the normal. In fact, for $\left[\mathrm{Ru}(\mathrm{CNpy})\left(\mathrm{NH}_{3}\right)_{4}(\mathrm{pyS})\right]^{2+}$, the shift of the X-sensitive band from $1102 \mathrm{~cm}^{-1}$ in the normal Raman spectrum to $1096 \mathrm{~cm}^{-1}$ in the SERS spectra, as well as a relative intensity decrease of the pyS out-of-plane modes from 300 to $800 \mathrm{~cm}^{-1}$, reinforce this assignment. The bands at 1016, 1196, 1278 and $1591 \mathrm{~cm}^{-1}$, assigned to the ring breathing, $\mathrm{CH}$ bending (1196 and $1278 \mathrm{~cm}^{-1}$ ), and $\mathrm{C}=\mathrm{C}$ and $\mathrm{C}=\mathrm{N}$ pyridine ring stretching, $\mathrm{v}(\mathrm{CC}+\mathrm{CN})$, modes, respectively, ${ }^{18,19,23-25}$ showed to be strongly affected by the applied potential. As the potential is scanned in the positive direction, there is an enhancement of the bands at 1096 and $1591 \mathrm{~cm}^{-1}$ at the expense of that at $1016 \mathrm{~cm}^{-1}$. This effect is assigned to the lower back-bonding from the surface and the ruthenium atom to the pyS moiety, which increases the double character of the $\mathrm{C}=\mathrm{S}$ bond and decreases the aromaticity of the pyridine ring, thus localizing the $\mathrm{C}=\mathrm{C}$ and $\mathrm{C}=\mathrm{N}$ bonds. Similar behavior is observed for the SAMs formed with $\left[\mathrm{M}(\mathrm{CN})_{5}(\mathrm{pyS})\right]^{3-}$ type complexes $(\mathrm{M}=\mathrm{Fe}$, $\mathrm{Ru}$ ) on gold. ${ }^{13}$ Contrary to what is currently reported for complexes in which the pyS ligand is the adsorption site, a gauche orientation has been observed on the surface for 1,4dt containing molecules..$^{14,49}$ The ex situ (without applied potential) SERS spectrum of $\left[\mathrm{Ru}(\mathrm{CNpy})\left(\mathrm{NH}_{3}\right)_{4}(1,4-\mathrm{dt})\right]^{2+}$ adsorbed on gold presents a relative intensity enhancement of the vibrational modes of the 1,4-dt ligand in comparison to those assigned to the CNpy moiety. According to the surface selection rules, ${ }^{54,55}$ this observation suggests that the former ligand is the adsorption site of the complex. ${ }^{14} \mathrm{~A}$ detailed discussion on the normal Raman and ex situ SERS spectra was already published in a previous paper. ${ }^{14}$ In the in situ (with applied potential) SERS spectra illustrated in Figure 1 (a), the intensity of the vibrational modes of these ligands depends on the applied potential. At positive potentials there is a relative intensity enhancement of the

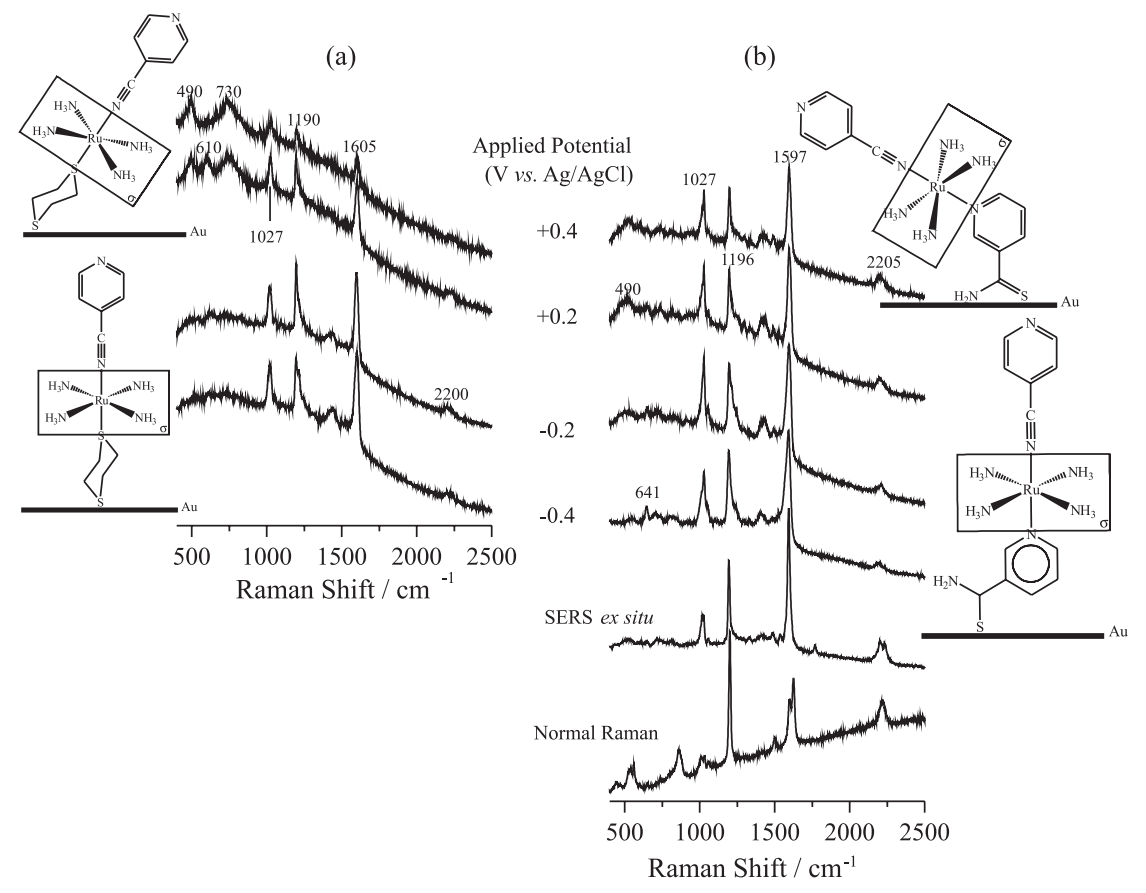

Figure 1. Normal Raman spectrum (bottom line) of $\left[\mathrm{Ru}(\mathrm{CNpy})\left(\mathrm{NH}_{3}\right)_{4}(\mathrm{tna})\right]\left(\mathrm{PF}_{6}\right)_{2}$ in the solid state and SERS spectra of the gold surfaces modified with (a) $\left[\mathrm{Ru}(\mathrm{CNpy})\left(\mathrm{NH}_{3}\right)_{4}(1,4-\mathrm{dt})\right]^{2+}$ and (b) $\left[\mathrm{Ru}(\mathrm{CNpy})\left(\mathrm{NH}_{3}\right)_{4}(\text { tna })\right]^{2+}$. In situ SERS spectra were obtained in $0.1 \mathrm{~mol} \mathrm{~L}^{-1} \mathrm{KCl}$ at different applied potentials. $\lambda_{0}=632.8 \mathrm{~nm}$. 
$v(\mathrm{CS})$ modes of the 1,4-dt ligand, whereas at negative potentials those modes assigned to the CNpy moiety (from 1000 to $1610 \mathrm{~cm}^{-1}$ ) are intensified. This observation suggests a dependence of the adsorbate conformation on the applied potential. In fact, for pure 1,4-dt adsorbed on gold, SERS spectra acquired with different focuses of the laser beam on the modified electrode show alternate enhancement of the 650 and $720 \mathrm{~cm}^{-1}$ bands assigned to the $v(\mathrm{CS})$ trans and gauche signals respectively. ${ }^{49}$ For the $\left[\mathrm{Ru}(\mathrm{CNpy})\left(\mathrm{NH}_{3}\right)_{4}(1,4-\mathrm{dt})\right]^{2+}$ complex on the surface, the $v(\mathrm{CS})$ trans and gauche signals are observed at 610 and $730 \mathrm{~cm}^{-1}$ respectively. In addition, the spectra obtained at +0.2 and $+0.4 \mathrm{~V}$ present a band at $490 \mathrm{~cm}^{-1}$ which is assigned ${ }^{56}$ to the $v(\mathrm{RuN})\left(\mathrm{NH}_{3}\right)$ mode. This observation indicates that the $\mathrm{NH}_{3}$ fragments are closer to the surface at positive applied potentials, as suggested by the inserts. Also in these spectra, the signal at $610 \mathrm{~cm}^{-1}$ is barely observed whereas that at $730 \mathrm{~cm}^{-1}$ is relatively intensified. Therefore, by accounting for the fact that the $\mathrm{NH}_{3}$ groups are on the equatorial plane, this result reinforces the suggestion of a conformation dependence on the applied potential.

In order to assign the adsorption site of the $[\mathrm{Ru}(\mathrm{CNpy})$ $\left(\mathrm{NH}_{3}\right)_{4}$ (tna) $]^{2+}$ complex, some points must be outlined in the ex situ SERS spectrum in comparison to the normal Raman spectrum, illustrated in Figure 1 (b). The region from 400 to $1000 \mathrm{~cm}^{-1}$, where the $v(\mathrm{CS})$ vibrational modes are observed, is the most affected by the adsorption on gold. Although presenting no meaningful frequency shifts in the ex situ SERS spectrum, a relative intensity enhancement is observed for the bands at 1597 and $1027 \mathrm{~cm}^{-1}$, assigned, ${ }^{27}$ respectively, to the $\delta\left(\mathrm{NH}_{2}\right)$ and $v(\mathrm{C}=\mathrm{S})$ modes of the $\mathrm{R}-\mathrm{C}\left(\mathrm{NH}_{2}\right)=\mathrm{S}$ group. It is suggested, therefore, that the adsorption occurs through the sulfur atom of the tna moiety. The proximity of the $\mathrm{NH}_{2}$ fragment, however, is affected by the applied potential as it can be seen in the in situ SERS spectra presented in Figure 1 (b) and the inserts. In addition, when the potential is scanned in the positive direction, a relative intensity enhancement of the band at $1027 \mathrm{~cm}^{-1}$ is observed in relation to the bands at 1196 and $1597 \mathrm{~cm}^{-1}$. This observation is consistent with a bonding localization on the tna moiety as a consequence of the decreasing $\pi$-back-bonding interaction since the ruthenium atom is being oxidized. In addition, at positive potentials, the $v(\mathrm{RuN})\left(\mathrm{NH}_{3}\right)$ mode $\left(490 \mathrm{~cm}^{-1}\right)$ is relatively intensified. Similar behavior is observed in the in situ SERS spectra of the $\left[\mathrm{Ru}(\mathrm{CNpy})\left(\mathrm{NH}_{3}\right)_{4}(1,4-\mathrm{dt})\right]^{2+} \mathrm{SAM}$ (Figure 1(a)). Accordingly, this result indicates a greater proximity of the $\mathrm{NH}_{3}$ fragments, as suggested by the diagrammatic representations of the complexes at the different applied potentials. Correlating the results obtained for the $\left[\mathrm{Ru}(\mathrm{CNpy})\left(\mathrm{NH}_{3}\right)_{4}(1,4-\mathrm{dt})\right]^{2+}$ and $[\mathrm{Ru}(\mathrm{CNpy})$
$\left(\mathrm{NH}_{3}\right)_{4}($ tna $\left.)\right]^{2+}$ SAMs with those obtained and/or reported for SAMs that contain the pyS moiety as adsorption site, one can conclude that the rigidity of the pyS species does not allow the dependence of the adsorbate conformation on the applied potential as the less or non-conjugated molecules (tna and 1,4-dt) do. This observation must present a direct relation with the electroactivity of these SAMs. Concerning the assessment of the heterogeneous electron transfer (hET) reaction of cytochrome c (cyt c) metalloprotein, for instance, the response obtained when the SAM formed with $\left[\mathrm{Ru}(\mathrm{CNpy})\left(\mathrm{NH}_{3}\right)_{4}(1,4-\mathrm{dt})\right]^{2+}$ is used is not as good as that observed for $\left[\mathrm{Ru}(\mathrm{CNpy})\left(\mathrm{NH}_{3}\right)_{4}(\mathrm{pyS})\right]^{2+},{ }^{14}$ which is trans to the surface. This electroactivity dependence on the conformation of the complexes on surface is corroborated by the result obtained for the $\left[\mathrm{Ru}(\mathrm{CNpy})\left(\mathrm{NH}_{3}\right)_{4}(\mathrm{tna})\right]^{2+}$ SAM toward the assessment of the cyt $\mathrm{c}$ hET reaction. The SAMs formed with both $\left[\mathrm{Ru}(\mathrm{CNpy})\left(\mathrm{NH}_{3}\right)_{4}(\mathrm{tna})\right]^{2+}$ and $\left[\mathrm{Ru}(\mathrm{CNpy})\left(\mathrm{NH}_{3}\right)_{4}(1,4-\mathrm{dt})\right]^{2+}$, which present gauche conformation on surface, show very similar responses. In addition, the suggestion of a gauche conformation justifies the more negative $\mathrm{E}_{\mathrm{rd}}$ value observed for the $[\mathrm{Ru}(\mathrm{CNpy})$ $\left(\mathrm{NH}_{3}\right)_{4}(\text { tna) }]^{2+} \mathrm{SAM}$ (Table 2), as this conformation allows a reasonable approach for the $\pi$ interaction to occur, thus implying a stronger interaction with the gold surface.

By taking into consideration the surface selection rules $^{5,55}$ and the known affinity of sulfur for gold surfaces, ${ }^{2}$ a relative intensity enhancement is expected for the vibrational modes of the adsorption site that contains a sulfur atom. However, the sulfur containing moiety of the $\left[\mathrm{Ru}(\mathrm{CNpy})\left(\mathrm{NH}_{3}\right)_{4}(\underline{\mathrm{NCS}})\right]^{+}$complex presents bands of very low intensity compared to the CNpy ligand, making the analysis of the spectra difficult; this can be seen in Figure 2(a). For the sake of clarity, the SERS spectra of $\left[\mathrm{Ru}(\underline{\mathrm{NCS}})\left(\mathrm{NH}_{3}\right)_{4}(\underline{\mathrm{NCS}})\right]$ adsorbed on gold (Figure 2(b)) are also presented, since there are no additional high intensity bands from aromatic species. The region from 400 to $1000 \mathrm{~cm}^{-1}$ was magnified because of the low signal to noise ratio. The SERS spectra of the $[\mathrm{Ru}(\mathrm{CNpy})$ $\left.\left(\mathrm{NH}_{3}\right)_{4}(\mathrm{NCS})\right]^{+}$complex adsorbed on gold are dominated by the cyanopyridine vibrations from 900 to $2000 \mathrm{~cm}^{-1}$. The frequency of these modes, however, does not change in comparison with the normal Raman spectrum of the complex in the solid state (bottom line in Figure 2(a)). On the contrary, the bands observed in the normal Raman spectrum at 2040 and $854 \mathrm{~cm}^{-1}$, assigned to the $v(\mathrm{C}=\mathrm{N})$ and $v(\mathrm{C}=\mathrm{S})$ vibrations of the $\mathrm{NCS}^{-}$moiety, respectively, shift to $c a .2120$ and $765 \mathrm{~cm}^{-1}$ in the SERS spectra. This result suggests that the $\left[\mathrm{Ru}(\mathrm{CNpy})\left(\mathrm{NH}_{3}\right)_{4}(\underline{\mathrm{NCS}})\right]^{+}$ complex is adsorbed on gold via the sulfur atom of the $\mathrm{NCS}^{-}$fragment. This suggestion is reinforced by the observation that these vibrational modes present a similar 


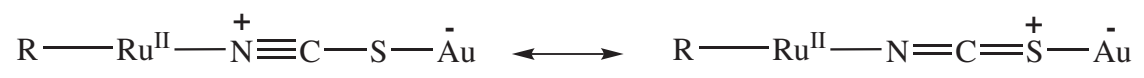

(a)

(b)

Scheme 1. Resonance structures suggested for the $\mathrm{NCS}^{-}$moiety upon adsorption on gold surface.

behavior in the $\left[\mathrm{Ru}(\underline{\mathrm{NCS}})\left(\mathrm{NH}_{3}\right)_{4}(\underline{\mathrm{NCS}})\right]$ complex, i.e., there is a shift from 2007 and $823 \mathrm{~cm}^{-1}$ in the normal Raman to ca. 2120 and $760 \mathrm{~cm}^{-1}$ in the SERS spectra (Figure 2(b)). Similar behavior is observed for the $\left[\mathrm{Ru}\left(\mathrm{dcbpyH}_{2}\right)_{2}(\mathrm{NCS})_{2}\right]$ and $\left[\mathrm{Ru}\left(\mathrm{NH}_{3}\right)_{5}(\underline{\mathrm{NCS}})\right]^{+}$complexes adsorbed on metallic surfaces, where dcbpy $=$ dicarboxybipyridine. ${ }^{57,58}$ The frequency shift can be explained on the assumption that, after adsorption, the double character of the CS bond decreases at the same time that the triple bond character of the $\mathrm{CN}$ bond increases. Theoretical studies on the adsorption of $\mathrm{NCS}^{-}$ion on silver ${ }^{59}$ reinforce this assignment and support the canonical forms suggested in Scheme 1.

The canonical form (b) is unlikely, since the higher softness of sulfur compared to nitrogen makes the localization of a positive charge on sulfur difficult. This $\underset{(a)}{\operatorname{means}}$ that the form (a) might prevail.
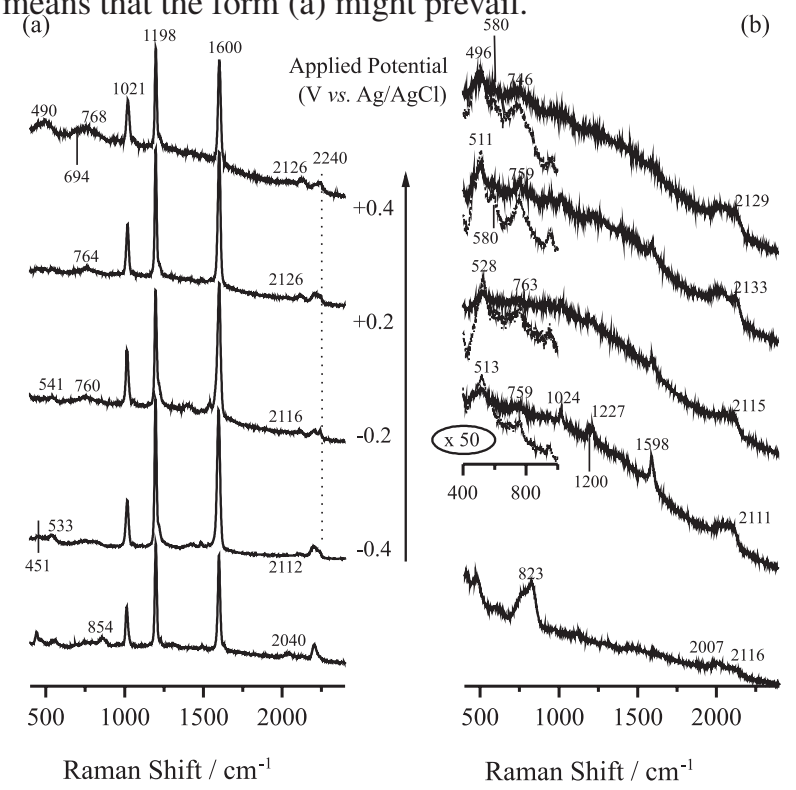

Figure 2. Normal Raman (bottom lines) and SERS spectra in $0.1 \mathrm{~mol} \mathrm{~L}^{-1}$ $\mathrm{KCl}$ of the gold electrode modified with (a) $\left[\mathrm{Ru}(\mathrm{CNpy})\left(\mathrm{NH}_{3}\right)_{4}(\underline{\mathrm{NCS}})\right]^{+}$and (b) $\left[\mathrm{Ru}(\underline{\mathrm{NCS}})\left(\mathrm{NH}_{3}\right)_{4}(\underline{\mathrm{NCS}})\right]$ at different applied potentials. $\lambda_{0}=632.8 \mathrm{~nm}$.

The in situ SERS spectra reinforce the assignment of the $\mathrm{NCS}^{-}$moiety as the adsorption site of the $[\mathrm{Ru}(\mathrm{CNpy})$ $\left.\left(\mathrm{NH}_{3}\right)_{4}(\underline{\mathrm{NCS}})\right]^{+}$complex on gold. For both the $[\mathrm{Ru}(\mathrm{CNpy})$ $\left.\left(\mathrm{NH}_{3}\right)_{4}(\underline{\mathrm{NCS}})\right]^{+}$and $\left[\mathrm{Ru}(\underline{\mathrm{NCS}})\left(\mathrm{NH}_{3}\right)_{4}(\underline{\mathrm{NCS}})\right]$ complexes, a frequency decrease of the $v(\mathrm{C}=\mathrm{N})$ mode is observed at negative applied potentials. Similar behavior is observed for the $\left[\mathrm{Ru}\left(\mathrm{NH}_{3}\right)_{5}(\underline{\mathrm{NCS}})\right]^{+}$complex upon adsorption on silver surface..$^{58}$ Therefore, this result can be considered an irrefutable indication of adsorption through the sulfur atom of the $\mathrm{NCS}^{-}$moiety. For the $\left[\mathrm{Ru}(\mathrm{CNpy})\left(\mathrm{NH}_{3}\right)_{4}(\mathrm{NCS})\right]^{+}$ complex, the frequency shift dependence of the $v(\mathrm{C}=\mathrm{N})$ mode on the applied potential is assigned to the electronic delocalization toward the CNpy ligand as the $\pi$-backbonding interaction is increased. At negative potentials, this interaction is intensified, thus decreasing the electronic density on the thiocyanate $\mathrm{CN}$ bond. As a consequence, the frequency of this vibrational mode is reduced.

\section{Experimental}

\section{Apparatus}

Elemental analyses were carried out at the Institute of Chemistry, São Paulo University, Brazil. Electronic spectra in the ultraviolet and visible regions were acquired with a Hitachi model U-2000 spectrophotometer. Chromatographic analyses were performed with a Shimadzu liquid chromatograph equipped with an LC-10AD pump and an SPD-M10A UV-Vis photodiodearray detector with a CBM-10AD interface. An ODS column from Supelco $(250 \mathrm{~mm} \times 4.6 \mathrm{~mm}, 5 \mu \mathrm{m}$ particles, C-18) was used for an isocratic elution with 10:90 acetonitrile:water containing $0.1 \% \mathrm{CF}_{3} \mathrm{COOH}(\mathrm{pH} 3.7$ ). The chromatograms were taken at a constant flow rate of $1.0 \mathrm{~mL} \mathrm{~min}{ }^{-1}$. Samples were dissolved in the mobile phase and volumes of $5 \mu \mathrm{L}$ were injected. The transmission infrared spectra of the compounds dispersed in $\mathrm{KBr}$ were obtained with a Perkin-Elmer Spectrum 1000 instrument. SERS and normal Raman spectra were acquired with a Renishaw Raman 3000 system equipped with a CCD (charge-coupled device) detector and an Olympus (BTH2) microscope with a $50 \times$ objective to focus the laser beam on the sample in a backscattering configuration. The $632.8 \mathrm{~nm}$ line from a He-Ne (Spectra-Physics) laser was used as exciting radiation, $\lambda_{0}$. Electrochemical experiments were performed on a Bioanalytical Systems $100 \mathrm{~W}$ electrochemical analyzer (BAS, West Lafayette, IN) at $25 \pm 0.2{ }^{\circ} \mathrm{C}$, employing a three-electrode glass cell with two platinum disks $\left(0.126 \mathrm{~cm}^{2}\right.$ of geometrical area) as working and auxiliary electrodes. A $0.5 \mathrm{~mol} \mathrm{~L}^{-1}$ aqueous solution ( $\mathrm{pH}$ 3.4) of $\mathrm{CF}_{3} \mathrm{COONa}$ was used as electrolyte for the characterization of the sulfate complexes. The non-aqueous experiments were carried out in acetonitrile containing $0.1 \mathrm{~mol} \mathrm{~L}^{-1}$ tetra- $n$-butylammonium perchlorate 
(tbap) as supporting electrolyte and ferrocene as internal reference. These measurements were referenced to an $\mathrm{Ag} \mid \mathrm{AgCl}$ electrode, which was prepared by immersion of an $\mathrm{Ag}$ foil in a saturated $\mathrm{KCl}$ solution for $1 \mathrm{~h}$ and then placed in a glass tube containing the same electrolyte to avoid junction potential contributions. All electrochemical data, unless otherwise specified, are cited against the Normal Hydrogen Electrode (NHE). To adjust the potentials to the NHE, the ferrocenium/ferrocene couple was assumed to lie at $0.665 v s$. NHE in acetonitrile. ${ }^{60}$ Gold surfaces were mechanically polished with alumina paste of different grades to a mirror finish, rinsed and sonicated (10 min) in Milli-Q water. They were then immersed in a freshly prepared "piranha solution" ( $3: 1$ concentrated $\mathrm{H}_{2} \mathrm{SO}_{4} / 30 \%$ $\mathrm{H}_{2} \mathrm{O}_{2}$; CAUTION: Piranha solution is a highly oxidant mixture that reacts violently with organic compounds), rinsed exhaustively with water, and sonicated again. The cleanness was evaluated by comparison of the i-E curve obtained in a $0.5 \mathrm{~mol} \mathrm{~L}^{-1} \mathrm{H}_{2} \mathrm{SO}_{4}$ solution with the wellestablished curve for a clean gold surface. ${ }^{61}$ After this procedure, the surface was modified by immersing the gold electrodes in a $2.0 \mathrm{mmol} \mathrm{L}^{-1}$ aqueous solution of the complexes for $30 \mathrm{~min}$. Reductive desorption potential $\left(\mathrm{E}_{\mathrm{rd}}\right)$ and reductive desorption charge density $\left(\sigma_{\mathrm{rd}}\right)$ parameters were determined from linear sweep voltage (LSV) experiments acquired in $0.5 \mathrm{~mol} \mathrm{~L}^{-1} \mathrm{KOH}$ aqueous solution within a potential range from 0.0 to $-1.2 \mathrm{~V} v \mathrm{~s}$. $\mathrm{Ag}|\mathrm{AgCl}| \mathrm{Cl}^{-}$ (3.5 $\left.\mathrm{mol} \mathrm{L}^{-1} \mathrm{KCl}, \mathrm{BAS}\right)$. These measurements were repeated at least three times to assure that only one redox process was observed, since multiple waves are reported for surfaces where different adsorption sites are presented. ${ }^{47}$

\section{Chemicals}

The water used throughout the experiments was purified from a Milli-Q water system (Millipore Co.). Organic solvents (Merck and Aldrich) of spectroscopic grade were used as received. 1,4-dithiane (1,4-dt), 4-mercaptopyridine (pyS), 4-cyanopyridine (CNpy), sodium thiocyanate, thionicotinamide (tna), $\mathrm{KCl}, \mathrm{KCN}$, $\mathrm{CF}_{3} \mathrm{COONa}$ and $\mathrm{KH}_{2} \mathrm{PO}_{4}$ were purchased from Aldrich and used as received. Tetra- $n$-butylammonium perchlorate (tbap), also from Aldrich, was recrystallized three times from ethyl acetate and dried under vacuum for $72 \mathrm{~h}$. Acetonitrile (chromatographic grade, Aldrich) was dried over $4 \AA$ molecular sieves for $72 \mathrm{~h}$ prior to use. The highpurity $\mathrm{H}_{2} \mathrm{SO}_{4}$, from Merck, was used as received. All other chemicals were of at least reagent grade quality and were used as received.

The starting complexes $\left[\mathrm{Ru}\left(\mathrm{NH}_{3}\right)_{5} \mathrm{Cl}\right] \mathrm{Cl}$, trans$\left[\mathrm{Ru}\left(\mathrm{SO}_{2}\right)\left(\mathrm{NH}_{3}\right)_{4} \mathrm{Cl}\right] \mathrm{Cl}$ and trans-[Ru(CNpy)$\left.\left(\mathrm{NH}_{3}\right)_{4}\left(\mathrm{SO}_{4}\right)\right]$
$\mathrm{Cl}$ were synthesized according to the literature. ${ }^{62,63}$ trans- $\left[\mathrm{Ru}(\mathrm{L})\left(\mathrm{NH}_{3}\right)_{4}\left(\mathrm{~L}^{\prime}\right)\right]\left(\mathrm{PF}_{6}\right)_{\mathrm{n}}$ type complexes were synthesized according to literature procedures for similar compounds. ${ }^{64-66}$ For all synthesized compounds, the obtained chromatograms presented only one peak indicating a high purity level. Their electrochemical characterization was carried out by cyclic voltammetry in aqueous and non-aqueous medium. All compounds presented well-defined waves assigned to the $\mathrm{Ru}^{\mathrm{IIIIII}}$ redox process with characteristics of high reversibility. In such case, the half-wave potential $\left(\mathrm{E}_{1 / 2}\right)$ values, calculated as the average between the anodic $\left(\mathrm{E}_{\mathrm{a}}\right)$ and cathodic $\left(\mathrm{E}_{\mathrm{c}}\right)$ potentials, $\mathrm{E}_{1 / 2}=\left(\mathrm{E}_{\mathrm{a}}+\mathrm{E}_{\mathrm{c}}\right) / 2$, can be approximated as the thermodynamic formal potential.

[Ru(CNpy) $\left(\mathrm{NH}_{3}\right)_{4}($ tna $\left.)\right]\left(\mathrm{PF}_{6}\right)_{2} \cdot 2 \mathrm{H}_{2} \mathrm{O}$ : Found: C, 19.50; $\mathrm{H}, 3.49 ; \mathrm{N}, 15.15 ; \mathrm{S}, 4.27 \%$. Calc. for $\mathrm{C}_{12} \mathrm{H}_{27} \mathrm{~F}_{12} \mathrm{~N}_{8} \mathrm{O}_{2} \mathrm{P} 2 \mathrm{RuS}$ : C, $19.54 ; \mathrm{H}, 3.55 ; \mathrm{N}, 15.19 ; \mathrm{S}, 4.35 \%$. Yield: $46 \%$. UV-Vis $\left(\mathrm{CH}_{3} \mathrm{CN}\right) \lambda_{\max }$ in $\mathrm{nm}\left(\varepsilon\right.$ in $\left.\mathrm{L} \mathrm{mol}^{-1} \mathrm{~cm}^{-1}\right): 250\left(9.40 \times 10^{3}\right)$, $543\left(3.40 \times 10^{3}\right) . \mathrm{E}_{1 / 2}\left(\mathrm{CH}_{3} \mathrm{CN}\right)=1.03 \mathrm{~V} v$ s. NHE.

[Ru(CNpy) $\left.\left(\mathrm{NH}_{3}\right)_{4}(\mathrm{CNpy})\right]\left(\mathrm{PF}_{6}\right)_{2} \cdot 2 \mathrm{H}_{2} \mathrm{O}$ : Found: C, 20.44; H, 3.39; N, 15.88\%. Calc. for $\mathrm{C}_{12} \mathrm{H}_{24} \mathrm{~F}_{12} \mathrm{~N}_{8} \mathrm{O}_{2} \mathrm{P}_{2} \mathrm{Ru}: \mathrm{C}$, $20.49 ; \mathrm{H}, 3.44 ; \mathrm{N}, 15.92 \%$. Yield: $65 \%$. UV-Vis $\left(\mathrm{CH}_{3} \mathrm{CN}\right)$ $\lambda_{\max }$ in $\mathrm{nm}\left(\varepsilon\right.$ in $\left.\mathrm{L} \mathrm{mol}^{-1} \mathrm{~cm}^{-1}\right): 213\left(2.88 \times 10^{3}\right), 248$ $\left(1.98 \times 10^{3}\right), 262\left(1.43 \times 10^{3}\right), 512\left(1.97 \times 10^{3}\right) \cdot \mathrm{E}_{1 / 2}\left(\mathrm{CH}_{3} \mathrm{CN}\right)$ $=1.10 \mathrm{~V} v s$. NHE.

$\left[\mathrm{Ru}(\mathrm{CNpy})\left(\mathrm{NH}_{3}\right)_{4}(\mathrm{CN})\right]\left(\mathrm{PF}_{6}\right) \cdot \mathrm{H}_{2} \mathrm{O}$ : Found: $\mathrm{C}, 18.41 ; \mathrm{H}$, $3.60 ; \mathrm{N}, 21.15 \%$. Calc. for $\mathrm{C}_{7} \mathrm{H}_{18} \mathrm{~F}_{6} \mathrm{~N}_{7} \mathrm{OPRu}: \mathrm{C}, 18.19 ; \mathrm{H}$, $3.92 ; \mathrm{N}, 21.21 \%$. Yield: $45 \%$. UV-Vis $\left(\mathrm{CH}_{3} \mathrm{CN}\right) \lambda_{\max }$ in nm $\left(\varepsilon\right.$ in $\left.\mathrm{L} \mathrm{mol}^{-1} \mathrm{~cm}^{-1}\right): 214\left(6.31 \times 10^{2}\right), 237\left(5.48 \times 10^{2}\right), 368$ $\left(2.39 \times 10^{2}\right), 446\left(1.05 \times 10^{3}\right) \cdot \mathrm{E}_{1 / 2}\left(\mathrm{CH}_{3} \mathrm{CN}\right)=0.79 \mathrm{~V} v s$. NHE.

$\left[\mathrm{Ru}(\mathrm{CNpy})\left(\mathrm{NH}_{3}\right)_{4}(\underline{\mathrm{NCS}})\right]\left(\mathrm{PF}_{6}\right) \cdot \mathrm{H}_{2} \mathrm{O}$ : Found: $\mathrm{C}, 16.97$; $\mathrm{H}, 3.61 ; \mathrm{N}, 19.78, \mathrm{~S}, 6.38 \%$. Calc. for $\mathrm{C}_{7} \mathrm{H}_{18} \mathrm{~F}_{6} \mathrm{~N}_{7} \mathrm{OPRuS}$ : C, $17.01 ; \mathrm{H}, 3.67 ; \mathrm{N}, 19.83, \mathrm{~S}, 6.49 \%$. Yield: $42 \%$. UV-Vis $\left(\mathrm{CH}_{3} \mathrm{CN}\right) \lambda_{\text {max }}$ in nm $\left(\varepsilon\right.$ in $\left.\mathrm{L} \mathrm{mol}^{-1} \mathrm{~cm}^{-1}\right): 215\left(3.04 \times 10^{3}\right), 261$ $\left(9.69 \times 10^{2}\right), 439\left(5.79 \times 10^{2}\right), 548\left(2.50 \times 10^{3}\right) \cdot \mathrm{E}_{1 / 2}\left(\mathrm{CH}_{3} \mathrm{CN}\right)$ $=0.65 \mathrm{~V} v s$. NHE.

$\left[\mathrm{Ru}(\underline{\mathrm{NCS}})_{2}\left(\mathrm{NH}_{3}\right)_{4}\right] \cdot \mathrm{H}_{2} \mathrm{O}$ : Found: $\mathrm{C}, 7.88 ; \mathrm{H}, 4.58 ; \mathrm{N}$, 27.62; S, 20.81\%. Calc. for $\mathrm{C}_{2} \mathrm{H}_{14} \mathrm{~N}_{6} \mathrm{ORuS}_{2}$ : C, 7.92; $\mathrm{H}$, 4.65; N, 27.70; S, $21.14 \%$. Yield: $69 \%$. UV-Vis $\left(\mathrm{CH}_{3} \mathrm{CN}\right)$ $\lambda_{\max }$ in $\mathrm{nm}\left(\varepsilon\right.$ in $\left.\mathrm{L} \mathrm{mol}^{-1} \mathrm{~cm}^{-1}\right): 223\left(4.67 \times 10^{2}\right), 279$ $\left(1.02 \times 10^{3}\right), 520\left(3.21 \times 10^{2}\right) . \mathrm{E}_{1 / 2}\left(\mathrm{CH}_{3} \mathrm{CN}\right)=0.03 \mathrm{~V} v s$. NHE.

$\left[\mathrm{Ru}(\mathrm{CN})\left(\mathrm{NH}_{3}\right)_{4}(\mathrm{pyS})\right]\left(\mathrm{PF}_{6}\right) \cdot 2 \mathrm{H}_{2} \mathrm{O}$ : Found: $\mathrm{C}, 14.71 ; \mathrm{H}$, 4.28; N, 17.18; S, 6.47\%. Calc. for $\mathrm{C}_{6} \mathrm{H}_{21} \mathrm{~F}_{6} \mathrm{~N}_{6} \mathrm{O}_{2} \mathrm{PRuS}: \mathrm{C}$, $14.79 ; \mathrm{H}, 4.34 ; \mathrm{N}, 17.24 ; \mathrm{S}, 6.58 \%$. Yield: $41 \%$. UV-Vis 
$\left(\mathrm{CH}_{3} \mathrm{CN}\right) \lambda_{\text {max }}$ in $\mathrm{nm}\left(\varepsilon\right.$ in $\left.\mathrm{L} \mathrm{mol}^{-1} \mathrm{~cm}^{-1}\right): 231\left(2.44 \times 10^{3}\right)$, $249\left(2.50 \times 10^{3}\right), 294\left(9.78 \times 10^{2}\right), 333\left(9.02 \times 10^{2}\right), 498$ $\left(7.18 \times 10^{2}\right) . \mathrm{E}_{1 / 2}\left(\mathrm{CH}_{3} \mathrm{CN}\right)=0.87 \mathrm{~V}$ vs. NHE.

$\left[\mathrm{Ru}(\underline{\mathrm{NCS}})\left(\mathrm{NH}_{3}\right)_{4}\left(\mathrm{SO}_{4}\right)\right] \cdot 2 \mathrm{H}_{2} \mathrm{O}$ : Found: $\mathrm{C}, 3.29 ; \mathrm{H}, 4.18$; $\mathrm{N}, 19.45 ; \mathrm{S}, 17.49 \%$. Calc. for $\mathrm{CH}_{16} \mathrm{~N}_{5} \mathrm{O}_{6} \mathrm{RuS}_{2}: \mathrm{C}, 3.34 ; \mathrm{H}$, $4.49 ; \mathrm{N}, 19.49 ; \mathrm{S}, 17.85 \%$. Yield: $80 \%$. UV-Vis $\left(\mathrm{H}_{2} \mathrm{O}\right) \lambda_{\max }$ in $\mathrm{nm}\left(\varepsilon\right.$ in $\left.\mathrm{L} \mathrm{mol}^{-1} \mathrm{~cm}^{-1}\right)$ : $225\left(4.85 \times 10^{3}\right), 328\left(4.66 \times 10^{3}\right)$. $\mathrm{E}_{1 / 2}\left(\mathrm{H}_{2} \mathrm{O}\right)=-0.14 \mathrm{~V} v s$. NHE.

$\left[\mathrm{Ru}(\mathrm{pyS})\left(\mathrm{NH}_{3}\right)_{4}\left(\mathrm{SO}_{4}\right)\right] \mathrm{Cl} \cdot 3 \mathrm{H}_{2} \mathrm{O}$ : Found: $\mathrm{C}, 12.82 ; \mathrm{H}$, 4.63; N, 14.95; S, 13.48\%. Calc. for $\mathrm{C}_{5} \mathrm{H}_{23} \mathrm{ClN}_{5} \mathrm{O}_{7} \mathrm{RuS}_{2}: \mathrm{C}$, $12.89 ; \mathrm{H}, 4.98 ; \mathrm{N}, 15.03$; S, $13.76 \%$. Yield: $83 \%$. UV-Vis $\left(\mathrm{H}_{2} \mathrm{O}\right) \lambda_{\max }$ in $\mathrm{nm}\left(\varepsilon\right.$ in $\left.\mathrm{L} \mathrm{mol}^{-1} \mathrm{~cm}^{-1}\right): 253\left(2.71 \times 10^{3}\right), 285$ $\left(3.08 \times 10^{3}\right), 323\left(3.70 \times 10^{3}\right), 454\left(2.47 \times 10^{3}\right) . \mathrm{E}_{1 / 2}\left(\mathrm{H}_{2} \mathrm{O}\right)=$ $0.27 \mathrm{~V}$ vs. NHE.

\section{Conclusions}

For the isolated trans- $\left[\mathrm{Ru}(\mathrm{CNpy})\left(\mathrm{NH}_{3}\right)_{4}\left(\mathrm{~L}^{\prime}\right)\right]\left(\mathrm{PF}_{6}\right)_{\mathrm{n}}$ type complexes, results hint that, when the $\pi$ withdrawing capability of the L' ligand is significantly different from that of the CNpy moiety, the competition for the electronic density on the $\mathrm{z}$ axis is decreased, thus making easier the oxidation of the metal center. On the other hand, when the L' and CNpy ligands present similar $\pi$ withdrawing capability, the electronic density is shared through the $\mathrm{z}$ axis, increasing the effective nuclear charge of the metal center. This electronic delocalization affects the stability of the monolayers formed with the complexes. Comparatively to the SAM formed with free 1,4-dt, for instance, the reductive desorption potential observed for the $[\mathrm{Ru}(\mathrm{CNpy})$ $\left.\left(\mathrm{NH}_{3}\right)_{4}(1,4-\mathrm{dt})\right]^{2+}$ SAM presents a positive shift, which means that it is more easily desorbed from the gold surface.

\section{Supplementary Information}

Supplementary data (Figures S1 and S2) are available free of charge at http://jbcs.sbq.org.br, as a PDF file.

\section{Acknowledgments}

The authors are thankful to the Brazilian agencies CNPq, CAPES and FAPESP for financial support. I. C. N. Diógenes, L. G. de F. Lopes and E. Longhinotti are research career awardees of the Conselho Nacional de Desenvolvimento Científico e Tecnológico (CNPq).

\section{References}

1. Stine, R.; Petrovykh, D. Y.; J. Elec. Spectrosc. Related Phenom.
2009, 172, 42.

2. Ulman, A.; Chem. Rev. 1996, 96, 1533.

3. Dubois, L. H.; Nuzzo, R. G.; Ann. Phys. Chem. 1992, 43, 437.

4. Wang, W.; Lee, T.; Reed, M. A.; Phys. Rev. B 2003, 68, 035416.

5. Lahan, J.; Mitragotri, S.; Tran, T. N.; Kaido, H.; Sundaram, J.; Choi, I. S.; Hoffer, S.; Somorjai, G. A.; Langer, R.; Science 2003, 299, 371.

6. Léger, C.; Bertrand, P.; Chem. Rev. 2008, 108, 2379.

7. Diógenes, I. C. N.; Nart, F. C.; Temperini, M. L. A.; Moreira, I. S.; Inorg. Chem. 2001, 40, 4884.

8. Davis, F.; Higson, S. P. J.; Biosens. Bioelectron. 2005, 21, 1.

9. James, D. K.; Tour, J. M.; Chem. Mater. 2004, 16, 4423.

10. Gorman, C. B.; Carroll, R. L.; Fuierer, R. R.; Langmuir 2001, 17, 6923 .

11. Sellers, H.; Ulman, A.; Shnidman, Y.; Eilers, J. E.; J. Am. Chem. Soc. 1993, 115, 9389.

12. Taube, H. In Survey of Progress in Chemistry; Scott, A. F., ed.; Academic Press: New York, 1973.

13. Diógenes, I. C. N.; Carvalho, I. M. M.; Longhinotti, E.; Lopes, L. G. F.; Temperini, M. L. A.; Andrade, G. F. S.; Moreira, I. S.; J. Electroanal. Chem. 2007, 605, 1.

14. Pinheiro, S. O.; Silva, F. O. N.; Carvalho, I. M. M.; Lopes, L. G. F.; Temperini, M. L. A.; Andrade, G. F. S.; Moreira, I. S.; Diógenes, I. C. N.; J. Braz. Chem. Soc. 2006, 17, 1594.

15. Pinheiro, S. O.; Sousa, J. R.; Santiago, M.O.; Carvalho, I. M. M.; Silva, A. L. R.; Batista, A. A.; Castellano, E. E.; Ellena, J.; Moreira, I. S.; Diógenes, I. C. N.; Inorg. Chim. Acta 2006, 359, 391.

16. Baldwin, J.; Schuler, N.; Butler, I. S.; Andrews, M. P.; Langmuir 1996, 12, 6389.

17. Bryant, M. A.; Joa, S. L.; Pemberton, J. E.; Langmuir 1992, 8, 753.

18. Joo, H. T.; Kim, M. S.; Kim, K.; J. Raman Spectrosc. 1987, 18, 57.

19. Spinner, E.; J. Chem. Soc. 1960, 1237.

20. Allinger, N. L.; Hickey, M. J.; J. Am. Chem. Soc. 1975, 97, 5167.

21. Oh, S. T.; Kim, K.; Kim, M. S.; J. Mol. Struct. 1991, 243, 307.

22. Hayasaki, K.; J. Chem. Soc. Jpn. 1960, 81, 1645.

23. Colthup, N. B.; Daly, L. H.; Wiberley, S. E.; Introduction to Infrared and Raman Spectroscopy, $2^{\text {nd }}$ ed., Academic Press: New York, 1975.

24. Varsanyi, G.; Assignments for Vibrational Spectra of Seven Hundred Benzene Derivatives, John Wiley \& Sons: New York, 1974.

25. Green, J. H. S.; Kynaston, W.; Paisley, H. M.; Spectrochim. Acta 1963, 19, 549.

26. Nakamoto, K.; Infrared and Raman Spectra of Inorganic and Coordination Compounds, $3^{\text {rd }}$ ed., John Wiley \& Sons: New York, 1978.

27. Rao, C. N. R.; Venkataraghavan, R.; Spectrochim. Acta 1962 , 
$18,541$.

28. Schmkidtke, H. H.; Garthoff, D.; Helv. Chim. Acta 1967, 50, 1631.

29. Kmell, P. O.; Strandberg, B.; Acta Chem. Scand. 1959, 13, 1607.

30. Jones, L. H.; J. Chem. Phys. 1956, 25, 1069.

31. Bailey, R. A.; Kozak, S. L.; Michelsen, T.-W.; Mills, W. N.; Coord. Chem. Rev. 1971, 6, 407.

32. Mitchell, P. C. H.; Williams, R. J. P.; J. Chem. Soc. 1960, 1912.

33. Huang, H.-Y.; Chen, W.-J.; Yang, C.-C.; Yeh, A.; Inorg. Chem. 1991, 30, 1862.

34. Clarke, R. E.; Ford, P. C.; Inorg. Chem. 1970, 9, 495.

35. Kuehn, C. G.; Isied, S. S.; Prog. Inorg. Chem. 1979, 27, 153.

36. Curtis, J. F.; Sullivan, B. P.; Meyer, T. J.; Inorg. Chem. 1983, $22,224$.

37. Zwickel, A.; Creutz, C.; Inorg. Chem. 1971, 10, 2395.

38. Ford, P. C.; Rudd, F. P.; Gaunder, R.; Taube, H.; Inorg. Chem. 1968, 90, 1187.

39. Brito, R. M.C.; Batista, A. A.; Ellena, J.; Castellano, E. E.; Diógenes, I. C. N.; Lopes, L. G. F.; Sousa, J. R.; Moreira, I. S.; Inorg. Chem. Comm. 2007, 10, 1515.

40. Bailey, R. A.; Kozak, S. L.; Michelsen, T. W.; Mills, W. N.; Coord. Chem. Rev. 1971, 6, 407.

41. Anson, F. C.; Acc. Chem. Res. 1975, 8, 400.

42. Matsubara, T.; Ford, P. C.; Inorg. Chem. 1976, 15, 1107.

43. Widrig, C. A.; Chung, C.; Porter, M. D.; J. Electroanal. Chem. 1991, 310, 335.

44. Kawaguchi, T.; Yasuda, H.; Shimazu, K.; Porter, M. D.; Langmuir 2000, 16, 9830.

45. Schneider, T. W.; Buttry, D. A.; J. Am. Chem. Soc. 1993, 115, 12391.

46. Walczak, M. M.; Alves, C. A.; Lamp, B. D.; Porter, M. D.; J. Electroanal. Chem. 1995, 396, 103.

47. Zhong, C.-J.; Porter, M. D.; J. Am. Chem. Soc. 1994, 116, 11616.

48. Lamp, B. D.; Hobara, D.; Porter, M. D.; Niki, K.; Cotton, T. M.; Langmuir 1997, 13, 736.

49. Sousa, J. R.; Batista, A. A.; Diógenes, I. C. N.; Andrade, G. F. S.; Temperini, M. L. A.; Lopes, L. G. F.; Moreira, I. S.;
J. Electroanal. Chem. 2003, 543, 93.

50. Diógenes, I. C. N.; Sousa, J. R.; Carvalho, I. M. M.; Temperini, M. L. A.; Tanaka, A. A.; Moreira, I. S.; Dalton Trans. 2003, 2231.

51. Diógenes, I. C. N.; Nart, F. C.; Temperini, M. L. A.; Moreira, I. S.; Electroanalysis 2002, 14, 153.

52. Diógenes, I. C. N.; Nart, F. C.; Moreira, I. S.; Inorg. Chem. 1999, 38, 1646.

53. Paulo, T. F.; Pinheiro, S. O.; Silva, M. A. S.; Lopes, L. G. F.; Pinheiro, L. S.; Aquino, G. F.; Temperini, M. L. A.; Lima-Neto, P.; Diógenes, I. C. N.; Electroanalysis 2009, 21, 1081.

54. Lombardi, J. R.; Birke, R. L.; J. Phys. Chem. C 2008, 112, 5605. 55. Lombardi, J. R.; Birke, R. L.; Acc. Chem. Res. 2009, $42,734$. 56. Allen, A. D.; Bottomley, F.; Harris, R. O.; Reinsalu, V. P.; Senoff, C. V.; J. Am. Chem. Soc. 1967, 89, 5595.

57. Leon, C. P.; Kador, L.; Peng, B.; Thelakkat, M. J. Phys. Chem. B 2005, 109, 5783.

58. Tadayyoni, M. A.; Farquharson, S.; Li, T. T.-T.; Weaver, M. J. J. Phys. Chem. 1984, 88, 4701.

59. Tielens, F.; Saeys, M.; Tourwé, E.; Marin, G. B.; Hubin, A.; Geerlings, P. J. Phys. Chem. A 2002, 106, 1450.

60. Gennett, T.; Milner, D. F.; Weaver, M. J.; J. Phys. Chem. 1985, 89, 2787.

61. Sawyer, D. T.; Sobkowiak, A.; Roberts Jr., J. L.; Electrochemistry for Chemists, John Wiley \& Sons: New York, 1995.

62. Vogt Jr., L. H.; Katz, J. L.; Wiberley, S. E.; Inorg. Chem. 1965, 4, 1157.

63. Silva, H. A. S.; McGarvey, B. R.; Santos, R. H. A.; Bertolti, M.; Mori, V.; Franco, D. W.; Can. J. Chem. 2001, 79, 679.

64. Tfouni, E.; Ford, P. C.; Inorg. Chem. 1980, 19, 72.

65. Isied, S. S.; Taube, H.; J. Am. Chem. Soc. 1981, 95, 8198.

66. Huang, H.-Y.; Chen, W.-J.; Yang, C.-C.; Yeh, A.; Inorg. Chem. 1991, 30, 1862.

Received: August 26, 2009

Web Release Date: April 22, 2010

FAPESP helped in meeting the publication costs of this article. 


\title{
On the Correlation between Electronic Intramolecular Delocalization and Au-S Bonding Strength of Ruthenium Tetraammine SAMs
}

\author{
Solange de O. Pinheiro, ${ }^{a}$ Tércio de F. Paulo, ${ }^{a}$ Maria A. S. da Silva, ${ }^{a}$ Gustavo F. S. Andrade, ${ }^{b}$ \\ Márcia L. A. Temperini, ${ }^{b}$ Idalina M. M. de Carvalho, ${ }^{a}$ Jackson R. de Sousa, ${ }^{a}$ Luiz G. de F. Lopes, ${ }^{a}$ \\ Francisco A. Dias-Filho, ${ }^{a}$ Eduardo H. S. Sousa, ${ }^{a}$ Elisane Longhinotti, ${ }^{c}$ Marcelo O. Santiago, ${ }^{d}$ \\ Ícaro de S. Moreira ${ }^{\dagger, a}$ and Izaura C. N. Diógenes $*, a$
}

${ }^{a}$ Departamento de Química Orgânica e Inorgânica, Universidade Federal do Ceará, CP 6021, 60455-970 Fortaleza-CE, Brazil

${ }^{b}$ Instituto de Química, Universidade de São Paulo, Cidade Universitária, CP 26077, 05599-970 São Paulo-SP, Brazil

'Departamento de Química Analítica e Físico-Química, Universidade Federal do Ceará, CP 6035, 60455-970 Fortaleza-CE, Brazil

${ }^{d}$ Campus Cariri, Universidade Federal do Ceará, Av. Tenente Raimundo Rocha s $n$, 63040-360 Juazeiro do Norte-CE, Brazil

The energies of the $\mathrm{CNpy}\left(\mathrm{p}_{\pi}{ }^{*}\right) \leftarrow\left(\mathrm{d}_{\pi}\right) \mathrm{Ru}^{\mathrm{II}}$ MLCT transitions of the isolated compounds were determined on the basis of the observation of an additional MLCT transition at higher energy, which was assigned to an MLCT transition involving the second ligand as acceptor (Inorg. Chem. 1983, 22, 224). In addition, the electronic spectra of the $\left[(\mathrm{CNpy}) \mathrm{Ru}\left(\mathrm{NH}_{3}\right)_{4}\left(\mathrm{H}_{2} \mathrm{O}\right)\right]^{2+}$ and $[(\mathrm{CNpy})$ $\left.\mathrm{Ru}\left(\mathrm{NH}_{3}\right)_{4}(\mathrm{CNpy})\right]^{2+}$ complexes, which are presented in Figure S1, were also used to determine the energy of the $\operatorname{CNpy}\left(\mathrm{p}_{\pi}^{*}\right) \leftarrow\left(\mathrm{d}_{\pi}\right) \mathrm{Ru}^{\mathrm{II}}$ MLCT transitions.

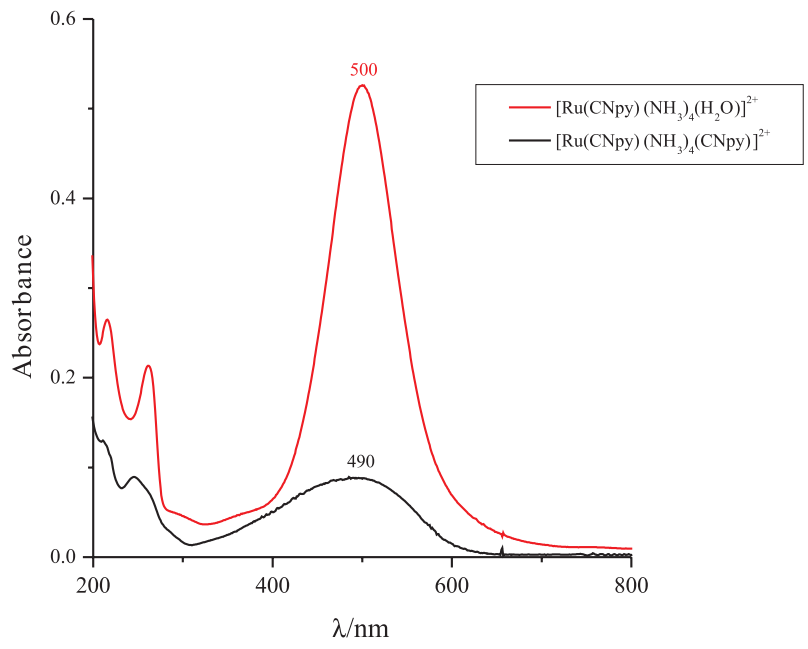

Figure S1. Electronic spectra of $\left[(\mathrm{CNpy}) \mathrm{Ru}\left(\mathrm{NH}_{3}\right)_{4}\left(\mathrm{H}_{2} \mathrm{O}\right)\right]^{2+}\left(5.2 \times 10^{-5}\right.$ $\left.\mathrm{mol} \mathrm{L}^{-1}\right)$ and $\left[(\mathrm{CNpy}) \mathrm{Ru}\left(\mathrm{NH}_{3}\right)_{4}(\mathrm{CNpy})\right]^{2+}\left(5.8 \times 10^{-6} \mathrm{~mol} \mathrm{~L}^{-1}\right)$ in water.

*e-mail: izaura@dqoi.ufc.br

$\dagger$ In memoriam
Linear sweep voltage (LSV) at $50 \mathrm{mV} \mathrm{s}^{-1}$ of the gold electrode modified with $\left[\mathrm{Ru}(\mathrm{CNpy})\left(\mathrm{NH}_{3}\right)_{4}(\mathrm{tna})\right]^{2+}$ in $0.5 \mathrm{~mol}$ $\mathrm{L}^{-1} \mathrm{KOH}$ solution is presented in Figure S2. Similar curves were obtained for the monolayers formed onto gold with the complexes that contain sulfur. The desorption curve obtained for the non-coordinated tna can be found in a previous publication (Electroanalysis 2009, 21, 1081). The surface coverage, $\Gamma$, was determined upon the integration of the area under the reductive peak which gives the reductive charge, $\mathrm{Q}_{\mathrm{rd}}$, and using the Equation $\Gamma=\sigma_{\mathrm{rd}} / \mathrm{nF}$, where $\sigma_{\mathrm{rd}}$ is the density of the reductive charge $\left(\sigma_{\mathrm{rd}}=\mathrm{Q}_{\mathrm{rd}} / A\right), \mathrm{n}$ is the number of electrons of the electrode reaction, $\mathrm{F}$ is the Faraday constant, and $\mathrm{A}$ is the electroactive area of the gold electrode.

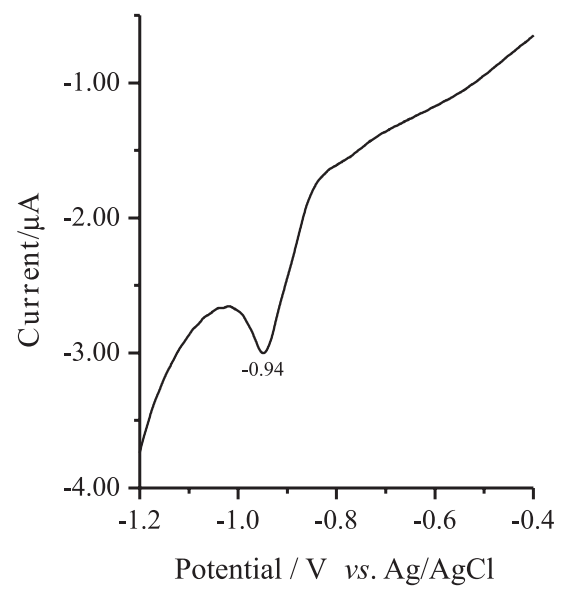

Figure S2. LSV curve at $50 \mathrm{mV} \mathrm{s}^{-1}$ of the gold electrode modified with $\left[\mathrm{Ru}(\mathrm{CNpy})\left(\mathrm{NH}_{3}\right)_{4}(\mathrm{tna})\right]^{2+}$ in $0.5 \mathrm{~mol} \mathrm{~L}^{-1} \mathrm{KOH}$ solution. The gold electrode was modified after $30 \mathrm{~min}$ of immersion in $2.0 \mathrm{mmol} \mathrm{L}^{-1}$ aqueous solution of the complex. 